\title{
Trends in atmospheric concentrations of weed pollen in the context of recent climate warming in Poznań (Western Poland)
}

\author{
Pawel Bogawski • Lukasz Grewling • Malgorzata Nowak • \\ Matt Smith • Bogdan Jackowiak
}

Received: 25 September 2013 / Revised: 12 December 2013 / Accepted: 18 December 2013 /Published online: 9 January 2014

(C) The Author(s) 2014. This article is published with open access at Springerlink.com

\begin{abstract}
A significant increase in summer temperatures has been observed for the period 1996-2011 in Poznań, Poland. The phenological response of four weed taxa, widely represented by anemophilous species (Artemisia spp., Rumex spp. and Poaceae and Urticaceae species) to this recent climate warming has been analysed in Poznan by examining the variations in the course of airborne pollen seasons. Pollen data were collected by 7-day Hirst-type volumetric trap. Trends in pollen seasons were determined using Mann-Kendall test and Sen's slope estimator, whereas the relationships between meteorological and aerobiological data were established by Spearman's rank correlation coefficient. Significant trends in pollen data were detected. The duration of pollen seasons of all analysed taxa increased (from +2.0 days/year for Urticaceae to +3.8 days/year for Rumex), which can be attributed to a delay in pollen season end dates rather than earlier start dates. In addition, the intensity of Artemisia pollen seasons significantly decreased and correlates with mean JulySeptember daily minimum temperatures $(r=-0.644, p<0.01)$. In contrast, no significant correlations were found between temperature and characteristics of Rumex pollen seasons. The
\end{abstract}

P. Bogawski $(\bowtie) \cdot$ Ł. Grewling $\cdot$ M. Nowak $\cdot$ B. Jackowiak Laboratory of Aeropalynology, Faculty of Biology, Adam Mickiewicz University, Umultowska 89, 61-614 Poznań, Poland e-mail: bogawski@amu.edu.pl

P. Bogawski

Department of Climatology, Faculty of Geographical and Geological Sciences, Adam Mickiewicz University, Dzięgielowa 27, 61-680 Poznań, Poland

M. Nowak

Department of Dermatology, University of Medical Science, Przybyszewskiego 49, 60-355 Poznań, Poland

M. Smith

Department of Oto-Rhino-Laryngology, Medical University of

Vienna, Vienna, Austria results of this study show that observed shifts in weed pollen seasons in Poznań, i.e. longer duration and later end dates, might be caused by the recorded increase in summer temperature. This influence was the strongest in relation to Artemisia, which is the taxon that flowers latest in the year. The general lack of significant correlations between Rumex and Urticaceae pollen seasons and spring and/or summer temperature suggests that other factors, e.g. land use practices, could also be partially responsible for the observed shifts in pollen seasons.

Keywords Climate change $\cdot$ Artemisia $\cdot$ Poaceae $\cdot$ Rumex . Urticaceae $\cdot$ Weed plants $\cdot$ Phenology $\cdot$ Temperature

\section{Introduction}

Climate change is generally characterised by the increasing trends of average annual surface temperature, which in Europe exceeded $0.9{ }^{\circ} \mathrm{C}$ for the period 1901-2005 (Solomon et al. 2007). The average temperature for the European land area for the last decade (2002-2011) was $1.3{ }^{\circ} \mathrm{C}$ above the preindustrial level, making it the warmest decade on record. Land temperatures, as well as the frequency and length of heat waves, is projected to increase over the twenty-first century (EEA 2012). It has been shown that the observed warming markedly affects the phenology of plants (Menzel et al. 2006; Gordo and Sanz 2009; Ziello et al. 2012a). Temperature increase is closely related to the longer growing season and advance of flowering time of plants (Walther et al. 2002). Some of these plants are of a great economic, ecological and health importance, and so it is essential to quantify any influence of climate variability on their phenophases (stage in a plant's life cycle), such as budburst, fructification and flowering (Peñuelas and Filella 2001).

The latter can be determined both by in situ observations (Leon-Ruiz et al. 2011; Sparks et al. 2011; Lessard-Therrien 
et al. 2013) and by indirect methods, i.e. estimating the concentration of pollen grains in the atmosphere (Tormo et al. 2011; Jochner et al. 2012). Direct field observations supply precise information of phenological phases of particular species; however, they are often time consuming and based on a limited number of investigated specimens (Soudani et al. 2012). Conversely, pollen concentrations in the air reflect the flowering time of plants growing on a relatively large area around the pollen trap (Skjøth et al. 2010). Even though the aerobiological data series has some limitations, such as the possibility of being biased by long-distance transport of pollen (Skjøth et al. 2007; Tormo et al. 2011), it is still suitable to determining a generalised flowering phenophase in a region.

The main objective of this study was to examine the effect of recent temperature increases recorded in Poznan (Western Poland) between 1996 and 2011 on certain characteristics of the pollen seasons of weeds with the highest airborne pollen concentrations.

\section{Methods}

Study area and climate

Poznań $\left(50-150\right.$ a.s.l., $\left.16^{\circ} 55^{\prime} \mathrm{E}, 52^{\circ} 25^{\prime} \mathrm{N}\right)$ is located in Western Poland (Wielkopolska province) with the population $\sim 550,000$ (CSO 2011). It has a temperate continental climate with cold winters and warm summers characterised by marked variability of weather phenomena. January is the coldest month of the year with the mean monthly temperature $-1.6^{\circ} \mathrm{C}$, whereas July is the warmest one $\left(18.1{ }^{\circ} \mathrm{C}\right)$. The mean annual precipitation is $517 \mathrm{~mm}$ (1951-2000 average) (Woś 2010). Daily mean, maximum and minimum temperatures were recorded at Lawica Airport ( $84 \mathrm{~m}$ a.s.l.), situated $4.25 \mathrm{~km}$ west of the pollen-monitoring site (Fig. 1), and supplied by the Institute of Meteorology and Water Management.

\section{Aerobiological data}

Daily average pollen counts (1996-2011) were collected by 7day volumetric spore trap of the Hirst design (Hirst 1952). The trap was located approximately $1 \mathrm{~km}$ from the city centre at the height of $33 \mathrm{~m}$ (Fig. 1). Two different pollen counting methods have been employed. From 1996 to 1999, the concentration of pollen grains in $1 \mathrm{~m}^{3}$ of air was calculated following the methods outlined by Stach (2000) where pollen grains were counted along 12 vertical transects. From 2000 to 2011, the four horizontal transects method recommended by Spanish Aerobiology Network was applied (Galán et al. 2007). The use of both vertical and horizontal transects has been shown to produce comparable results when similar percentages of the slide are examined (Comtois et al. 1999; Cariñanos et al. 2000). However, Kapyla and Penttinen

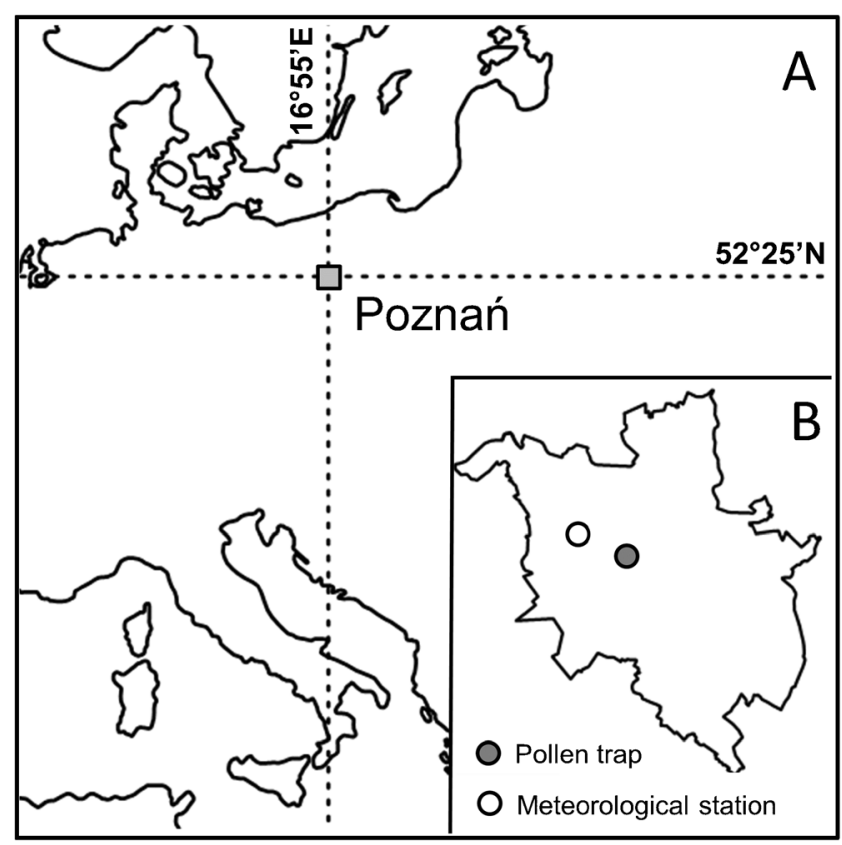

Fig. 1 Location of Poznań in Europe (a) and pollen trap as well as meteorological station within Poznań administrative boundaries (b)

(1981) stated that traverses along the length of the slide may give unreliable estimates because of the irregular transverse variation in the deposition of particles on the tape. The authors recommended that whole width of the tape should be studied because a considerable amount of particles were also found outside the $14 \mathrm{~mm}$ wide "effectively collecting area" below the orifice. Cotos-Yáñez et al. (2013) also reported that the distribution of pollen grains over vertical and horizontal transects is not uniform. However, it has also been shown that error is related to abundance of pollen grains on the slide, and the percentage of error diminishes as concentrations of pollen in the air increase (Tormo-Molina et al. 1996; Comtois et al. 1999). We examine weeds with the highest airborne pollen concentrations in Poznan, and so the use of different counting methods is not thought to influence the results of this study. The limits of pollen seasons were defined using the method proposed by García-Mozo et al. (2006) where the season start/ end was determined as the day on which the count was higher than 1 pollen grain $/ \mathrm{m}^{3}$, and that maintained itself through consecutive 5 days for start and proceeding 5 days for end of the pollen season. This method has already been used to calculate the limits of pollen seasons of weed species in Poznań (Stach et al. 2007; Alcázar et al. 2009). Due to trap failure during the 1998 pollen season, the dataset contained missing values, which were replaced by the mean daily average pollen count for that day (1996-2011 mean): 10 days, 2231 July 1998.

Four weed taxa, i.e. Artemisia spp., Rumex spp. as well as Poaceae and Urticaceae species, were chosen for further analysis. From now on, Artemisia spp., Rumex spp. and Urticaceae and Poaceae species are simply referred to as Artemisia, 
Rumex, Urticaceae and Poaceae. The most widespread Artemisia species in the city are A. vulgaris, A. absinthium and $A$. campestris (Jackowiak 1993), which often invade areas of disturbed soils, roadsides and derelict wastelands (Maw et al. 1985; Barney and DiTommaso 2003). The most common species of Poaceae, Rumex and Urticaceae in Poznań and its surroundings were previously described by Stach et al. (2008) and Alcázar et al. (2009). From a phytosociological point of view, Artemisia spp., Rumex spp. and species from Urticaceae family are characteristic taxa within the class Artemisietea vulgaris (Matuszkiewicz 2006). The class comprises nitrophilous plants growing on ruderal areas. These habitats are common both inside and in the outskirts of Poznań (Adamczak 2008). The considerable area (26 \%) covered by agricultural fields, wastelands and meadows in Poznań (MPU 2008) offers the habitats for the persistence of nitrophilous plant communities of the Artemisietea class.

In the study, we focused on examining the variation and trends of following characteristics of airborne pollen seasons:

1. Timing of pollen season, by investigating start, peak and end dates of the season; these data were converted to the day of the year from 1 January (DOY)

2. Intensity of pollen season by describing the seasonal pollen index (total amount of pollen during pollen season, SPI) and peak value (the highest daily pollen concentration)

3. Duration of pollen seasons.

\section{Statistical analysis}

In aerobiological studies, the impact of meteorological factors, especially temperature, on pollen season parameters is often analysed (Emberlin et al. 2002; Grewling et al. 2012a; Ziello et al. 2012b). However, the temperature data usually originate from only one station, and it is possible to be biased by the changes in the measuring instruments, station relocation, urban growth (changes in immediate environment) or observation practices (Karl and Williams 1987; Peterson et al. 1998). To minimise these effects, the relative homogenisation approach is commonly applied (Vincent et al. 2002). It assumes that nearby located stations are exposed to almost the same climate character and their data could be used to build a reference series or to pairwise comparison with tested (candidate) series. As a result, it is possible to detect and remove inhomogeneities in temperature data (Venema et al. 2012).

The monthly mean daily average, maximum and minimum temperature series (from April to September) were tested in order to detect the possible data inhomogeneity. Meteorological data from surrounding stations, i.e. Leszno $(70 \mathrm{~km}$ from Poznań), Piła (90 km) and Gorzów Wielkopolski (130 km) were used as a reference series. The temperature data were significantly correlated $(r=0.80-0.94, p<0.01$, data not shown) with the data from Poznań and with each other. Therefore, these series were used to perform the tests of data homogeneity:

1. Standard normal homogeneity test (SNHT) for shift to detect a sudden change in mean value of meteorological parameters (Alexandersson 1986)

2. SNHT for trends to detect a graduate, artificial change (Alexandersson and Moberg 1997)

3. Bivariate test (Potter 1981).

For the trend analysis, only homogenous series of monthly temperatures were taken into account. The evaluation of the statistical significance and the slope of the existing trend the non-parametric Mann-Kendall test and Sen's method have been used (Mann 1945; Kendall 1975; Salmi et al. 2002). The relationships between pollen season parameters and air temperature have been examined by Spearman's rank correlation coefficient. Only monthly temperature data that could potentially affect pollen season characteristics have been taken into account; for instance, meteorological data recorded before and during the pollen season were correlated with its duration and intensity, whereas pollen season start, peak and end dates were linked with temperature data recorded only before these aerobiological parameters. The analyses have been executed in the XLSTAT software (Addinsoft ${ }^{\mathrm{TM}}$, SARL), and in the MAKESENS application (Version 1.0 Freeware, Copyright Finnish Meteorological Institute). Creating reference series and the relative homogenisation testing of data have been conducted in ProClimDB and Anclim software packages (Stepanek 2008a, b).

\section{Results}

Meteorological data

Generally, for the period 1996-2011, the monthly temperature data series were homogeneous, although, in June, both SNHT and bivariate tests showed that there was an inhomogeneity in the mean daily maximum and minimum temperatures (Table 1). These two temperature series were rejected from further analyses. Mann-Kendall test and Sen's method revealed existence of six statistically significant temperature trends (Table 2; Fig. 2). All detected series were characterised by a significant temperature increase and the most distinct one was observed during the July-September period $\left(+0.16^{\circ} \mathrm{C} /\right.$ year, $\left.p<0.01\right)$.

Aerobiological data

\section{Timing of pollen seasons}

Amongst investigated taxa, the Poaceae pollen season started the earliest (mean=131 DOY, 11th of May) and became 
Table 1 Results of homogeneity testing

\begin{tabular}{|c|c|c|c|c|c|c|c|c|c|}
\hline \multirow[t]{3}{*}{ Month } & \multicolumn{9}{|c|}{ Homogeneity test } \\
\hline & \multicolumn{3}{|c|}{ SNHT shift } & \multicolumn{3}{|c|}{ SNHT trend } & \multicolumn{3}{|c|}{ Bivariate test } \\
\hline & $T_{\min }$ & $T_{\max }$ & $T_{\text {mean }}$ & $T_{\min }$ & $T_{\max }$ & $T_{\text {mean }}$ & $\underline{T}_{\min }$ & $T_{\max }$ & $T_{\text {mean }}$ \\
\hline April & 5.07 & 2.67 & 1.66 & 1.56 & 2.33 & 1.34 & 6.11 & 2.66 & 2.49 \\
\hline May & 2.32 & 3.00 & 4.33 & 1.77 & 0.60 & 3.16 & 3.34 & 3.97 & 5.59 \\
\hline June & $7.00 *$ & $9.22 *$ & 3.69 & 5.56 & $8.37^{*}$ & 3.59 & $7.42 *$ & $9.85^{*}$ & 6.28 \\
\hline July & 4.56 & 5.96 & 5.40 & 4.32 & 6.05 & 4.60 & 6.26 & 6.18 & 6.41 \\
\hline August & 1.66 & 2.32 & 6.14 & 1.34 & 1.98 & 5.01 & 2.88 & 2.75 & 6.65 \\
\hline September & 3.57 & 2.50 & 5.06 & 4.31 & 2.80 & 4.70 & 5.77 & 5.90 & 4.88 \\
\hline
\end{tabular}

Average minimum, maximum and mean monthly temperature series tested with three kinds of relative homogeneity test

${ }^{*} p<0.05$
Urticaceae, where a slight increase in SPI was recorded (not significant). The SPI and peak value of Artemisia were strongly affected by mean July-September daily average temperatures ( $r=-0.644, p<0.01$ and $r=-0.635, p<0.01$, respectively). The grass pollen seasons intensity showed significant relationships with mean April-July daily average temperatures $(r=-0.632, p<0.05)$. The same meteorological conditions also influenced the peak daily values of Poaceae $(r=$ $-0.631, p<0.05)$. No significant correlations were found between Rumex and Urticaceae pollen season intensity and selected weather parameters (Table 5).

\section{Duration of pollen seasons}

Compared to Artemisia (mean pollen season duration= 56 days), the pollen seasons of Poaceae, Rumex and Urticaceae were relatively long ( $>100$ days) (Table 3 ). Significant $(p<0.01)$ lengthening of pollen seasons were seen for all examined taxa and ranged from +2.0 (Urticaceae) to + 3.8 (Rumex)days/year (Table 4). The results of correlation analysis revealed significant $(p<0.01)$ positive relationships between mean July-September daily minimum temperatures and duration of Artemisia and Poaceae pollen seasons ( $r=$ 0.750 and $r=0.830$, respectively). Similarly to pollen season intensity, no significant correlations were found between

Table 2 Significant temperature trends in Poznań (1996-2011) calculated from homogeneous series: Mann-Kendall trend test (test $Z$ column), Sen's slope estimation ( $Q$ column) and the limits of confidence interval (95\%: $Q_{\min 95}$ and $Q_{\max }{ }_{95}$ )

\begin{tabular}{lllll}
\hline Temperature series & Test $Z$ & $Q$ & $Q_{\min 95}$ & $Q_{\max 95}$ \\
\hline$T_{\min }$ July $\left({ }^{\circ} \mathrm{C}\right)$ & $2.026^{*}$ & 0.18 & 0.004 & 0.372 \\
$T_{\min }$ July-September $\left({ }^{\circ} \mathrm{C}\right)$ & $2.746^{* *}$ & 0.16 & 0.063 & 0.209 \\
$T_{\min }$ July-August $\left({ }^{\circ} \mathrm{C}\right)$ & $2.476^{*}$ & 0.15 & 0.056 & 0.246 \\
$T_{\text {mean }}$ June-July $\left({ }^{\circ} \mathrm{C}\right)$ & $2.566^{*}$ & 0.18 & 0.030 & 0.297 \\
$T_{\text {mean }}$ April-July $\left({ }^{\circ} \mathrm{C}\right)$ & $2.026^{*}$ & 0.10 & 0.004 & 0.204 \\
$T_{\text {mean }}$ April-September $\left({ }^{\circ} \mathrm{C}\right)$ & $2.116^{*}$ & 0.12 & 0.015 & 0.198 \\
\hline
\end{tabular}

$*_{p}<0.05 ; * * p<0.01$ 


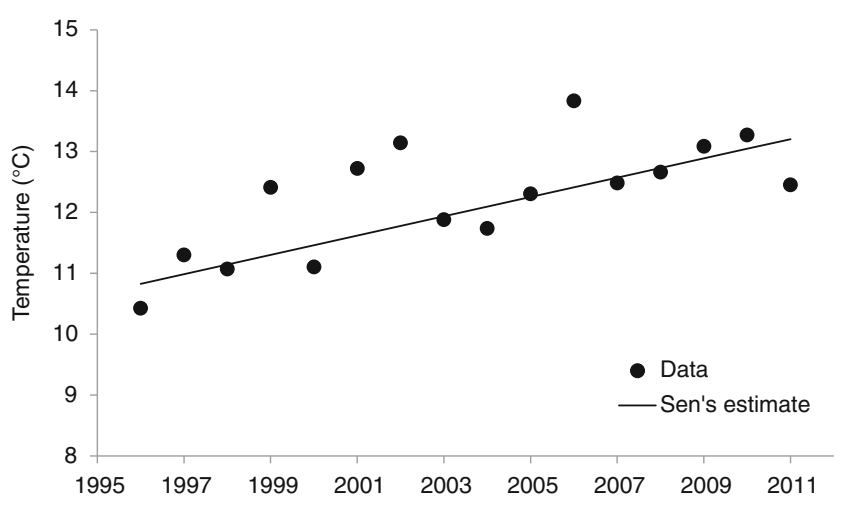

Fig. 2 Trend in mean minimum July-September temperature in Poznań (1996-2011). Mann-Kendall trend test (test $Z$ column), Sen's slope estimation ( $Q$ column), and the limits of confidence interval ( $95 \%$ : $Q_{\min 95}$ and $\left.Q_{\max 95}\right)$ are presented in Table 2

Rumex and Urticaceae pollen season duration and selected meteorological parameters (Table 5).

\section{Discussion}

In order to determine whether data variability is only caused by climate change, it is necessary to analyse homogenised time series. On average, one inhomogeneity is detected per
15-20 years in climatological data series (Venema et al. 2012). After homogeneity testing of mean monthly minimum, maximum and average temperature data recorded in Poznań, six trends in spring and summer temperatures have been identified as an effect of climate change. A number of significant trends in the characteristics of pollen seasons of anemophilous weed plants were simultaneously found in Poznań.

Timing of pollen seasons

The strongest shifts were related to Artemisia and Poaceae pollen seasons that started earlier and ended significantly later than they did in the mid-1990s. The observed advance of Artemisia pollination period $(-0.75$ day/year, $p<0.01)$ continues the tendency described in Poznan for the years 19952004 (Stach et al. 2007). It is worth noticing that Artemisia pollen season start dates significantly correlated with mean daily minimum temperatures in July $(r=-0.805, p<0.01)$, which significantly increased in Poznań over the same period $\left(+0.18{ }^{\circ} \mathrm{C} /\right.$ year, $\left.p<0.05\right)$. This observation agrees with previous studies (von Wahl and Puls 1989; Wolf et al. 1998) showing that high minimum temperatures accelerate the rate of development of Artemisia inflorescences and the release of its pollen. On the other hand, regional-scale studies showed that Artemisia pollen seasons were notable delayed in areas
Table 3 Descriptive statistics of pollen season parameters in Poznań, 1996-2011

\begin{tabular}{|c|c|c|c|c|c|c|c|}
\hline \multirow[t]{2}{*}{ Taxon } & \multirow{2}{*}{$\begin{array}{l}\text { Descriptive } \\
\text { statistics }\end{array}$} & \multicolumn{6}{|c|}{ Characteristics of pollen season } \\
\hline & & $\begin{array}{l}\text { Start date } \\
\text { (DOY) }\end{array}$ & $\begin{array}{l}\text { Peak date } \\
\text { (DOY) }\end{array}$ & $\begin{array}{l}\text { End date } \\
\text { (DOY) }\end{array}$ & $\begin{array}{l}\text { Duration } \\
\text { (days) }\end{array}$ & $\begin{array}{l}\text { Peak value } \\
\left(\mathrm{P} / \mathrm{m}^{3}\right)\end{array}$ & SPI (pollen) \\
\hline \multirow[t]{5}{*}{ Poaceae } & Max & 149 & 194 & 273 & 148 & 524 & 7,487 \\
\hline & Min & 116 & 149 & 230 & 100 & 108 & 2,272 \\
\hline & Mean & 131 & 177 & 256 & 124 & 279 & 4,100 \\
\hline & SD & 8.9 & 11.9 & 13.4 & 17.1 & 116.2 & $1,368.3$ \\
\hline & $\mathrm{CV}(\%)$ & 6.8 & 6.7 & 5.2 & 13.7 & 41.6 & 33.4 \\
\hline \multirow[t]{5}{*}{ Rumex spp. } & Max & 150 & 200 & 273 & 145 & 153 & 2,496 \\
\hline & Min & 119 & 131 & 206 & 83 & 22 & 282 \\
\hline & Mean & 134 & 169 & 249 & 115 & 51 & 1,147 \\
\hline & SD & 7.8 & 18.9 & 19.0 & 20.8 & 31.6 & 462.6 \\
\hline & $\mathrm{CV}(\%)$ & 5.8 & 11.2 & 7.6 & 18.0 & 62.1 & 40.3 \\
\hline \multirow[t]{5}{*}{ Urticaceae } & Max & 160 & 227 & 274 & 149 & 1080 & 22,414 \\
\hline & Min & 120 & 176 & 240 & 87 & 162 & 662 \\
\hline & Mean & 147 & 203 & 261 & 114 & 534 & 10,197 \\
\hline & SD & 11.6 & 13.4 & 11.3 & 16.9 & 312.2 & $5,728.9$ \\
\hline & CV (\%) & 7.9 & 6.6 & 4.3 & 14.8 & 58.5 & 56.2 \\
\hline \multirow[t]{5}{*}{ Artemisia spp. } & Max & 208 & 228 & 271 & 81 & 439 & 3,429 \\
\hline & Min & 189 & 209 & 241 & 36 & 35 & 369 \\
\hline & Mean & 198 & 219 & 253 & 56 & 137 & 1,421 \\
\hline & SD & 5.0 & 4.8 & 11.7 & 15.1 & 104.1 & 809.0 \\
\hline & CV (\%) & 2.5 & 2.2 & 4.5 & 27.0 & 75.9 & 56.9 \\
\hline
\end{tabular}


Table 4 Mann-Kendall trend test (test $Z$ column) and Sen's slope estimate ( $Q$ column) of pollen season parameters of weed taxa

\begin{tabular}{|c|c|c|c|c|c|c|c|c|}
\hline \multirow[t]{2}{*}{ Pollen season parameter } & \multicolumn{2}{|l|}{ Poaceae } & \multicolumn{2}{|c|}{ Rumex spp. } & \multicolumn{2}{|c|}{ Urticaceae } & \multicolumn{2}{|c|}{ Artemisia spp. } \\
\hline & Test $Z$ & $Q$ & Test $Z$ & $Q$ & Test $Z$ & $Q$ & Test $Z$ & $Q$ \\
\hline Start date (DOY) & $-2.12 *$ & -1.03 & -0.59 & -0.31 & -1.04 & -0.39 & $-2.86^{* *}$ & -0.75 \\
\hline End date (DOY) & $2.7 * *$ & 1.86 & $2.66^{* *}$ & 2.81 & $2.60 * *$ & 1.41 & $2.26^{*}$ & 1.27 \\
\hline Peak date (DOY) & -0.27 & -0.22 & 1.40 & 1.56 & -1.22 & -0.79 & 0.46 & 0.10 \\
\hline Duration (days) & $3.52 * *$ & 3.00 & $2.75 * *$ & 3.76 & $2.12 *$ & 2.00 & $2.75 * *$ & 2.49 \\
\hline Peak value $\left(\mathrm{P} / \mathrm{m}^{3}\right)$ & -0.81 & -6.56 & -1.67 & -1.50 & 0.41 & 7.96 & -1.76 & -7.32 \\
\hline SPI (pollen) & -0.41 & -58.5 & -1.22 & -11.75 & 1.49 & 517.17 & $-2.12 *$ & -81.33 \\
\hline
\end{tabular}

${ }^{*} p<0.05 ;{ }^{*} p<0.01$

where the mean June-July daily minimum temperatures exceeded $13{ }^{\circ} \mathrm{C}$ (Grewling et al. 2012b).

A previous study conducted in Poznań (Stach et al. 2008) showed that the onset of Poaceae pollen seasons was negatively affected $(p<0.01)$ by temperature recorded before pollen season start dates, particularly mean March-May daily average temperatures. However, due to the lack of a significant trend in temperature data during early spring, we did not investigate the relationship between temperature and Poaceae pollen season start dates. The onset of Rumex and Urticaceae pollen seasons also advanced in Poznan, but the observed trends were not statistically significant. In general, earlier start

Table 5 Spearman correlation coefficients between the pollen season parameters and homogenous monthly temperature series recorded in Poznań (1996-2011)

\begin{tabular}{|c|c|c|c|c|c|c|c|}
\hline Taxon & $\begin{array}{l}\text { Pollen season } \\
\text { parameter }\end{array}$ & $T_{\text {mean }}$ April-July & $T_{\text {mean }}$ April-September & $T_{\text {mean }}$ June-July & $T_{\min }$ July & $T_{\min }$ July-August & $T_{\min }$ July-September \\
\hline \multirow[t]{6}{*}{ Poaceae } & Start date & - & - & - & - & - & - \\
\hline & Peak date & $-0.625^{*}$ & - & ns & ns & - & - \\
\hline & End date & ns & ns & ns & $0.515 *$ & $0.627 *$ & $0.670 * *$ \\
\hline & Duration & ns & ns & $0.536^{*}$ & $0.649 * *$ & $0.780 * *$ & $0.830 * *$ \\
\hline & Peak value & $-0.631^{*}$ & ns & ns & ns & ns & ns \\
\hline & SPI & $-0.632 *$ & $-0.553^{*}$ & ns & ns & ns & ns \\
\hline \multirow[t]{6}{*}{ Rumex spp. } & Start date & - & - & - & - & - & - \\
\hline & Peak date & ns & - & ns & ns & - & - \\
\hline & End date & ns & ns & ns & ns & ns & ns \\
\hline & Duration & ns & ns & ns & ns & ns & ns \\
\hline & Peak value & ns & ns & ns & ns & ns & ns \\
\hline & SPI & ns & ns & ns & ns & ns & ns \\
\hline \multirow[t]{6}{*}{ Urticaceae } & Start date & - & - & - & - & - & - \\
\hline & Peak date & $-0.512 *$ & - & ns & ns & ns & - \\
\hline & End date & ns & ns & ns & ns & ns & ns \\
\hline & Duration & ns & ns & ns & ns & ns & ns \\
\hline & Peak value & ns & ns & ns & ns & ns & ns \\
\hline & SPI & ns & ns & ns & ns & ns & ns \\
\hline \multirow[t]{6}{*}{ Artemisia spp. } & Start date & $-0.562 *$ & - & $-0.728 * *$ & $-0.805^{* *}$ & - & - \\
\hline & Peak date & ns & - & ns & ns & ns & - \\
\hline & End date & ns & ns & ns & $0.552 *$ & $0.565^{*}$ & $0.626^{*}$ \\
\hline & Duration & $0.532 *$ & $0.691 * *$ & $0.686^{* *}$ & $0.732 * *$ & $0.670 * *$ & $0.750 * *$ \\
\hline & Peak value & ns & ns & $-0.629 *$ & $-0.547 *$ & ns & $-0.635^{* *}$ \\
\hline & SPI & ns & ns & $-0.571^{*}$ & $-0.521 *$ & $-0.615^{*}$ & $-0.644 * *$ \\
\hline
\end{tabular}

$n s$ not significant

${ }^{*} p<0.05,{ }^{* *} p<0.01$ 
dates of pollen seasons of weed plants was recorded across Europe during the last decades (Frenguelli 2002; Van Vliet et al. 2002; Clot 2003; García-Mozo et al. 2010a; Makra et al. 2011), and most of this changes might be related to the recent temperature increase. In some regions, e.g. in Southern Europe, these tendencies are not so distinct and in a few cases the delay of pollen seasons was noticed (Damialis et al. 2007; Recio et al. 2009; Recio et al. 2010; Tormo-Molina et al. 2010) and could be linked to the influence of water availability on plant growth and development in these regions (GarcíaMozo et al. 2009, García-Mozo et al. 2010b; Recio et al. 2010). It should therefore be noted that Wielkopolska is one of the driest regions in Poland (Woś 2010) and further shortage of rainfall, as projected for Central Europe (EEA 2012), might possibly affect the course of pollen seasons. However, no significant decreases in rainfall were recorded during the studied period, and as a result, this parameter was not considered to be responsible for the temporal changes in weed pollen seasons in Poznań.

\section{Intensity of pollen seasons}

The Artemisia pollen index significantly decreased in Poznań. A similar trend was noticed in Szczecin, located around 200 km North-West from Poznań (Puc and Wolski 2013) as well as in many sites in Europe (Ziello et al. 2012b). Our study revealed that Artemisia pollen season intensity was significantly negatively correlated with minimum temperatures during the summer months. These results generally agree with studies performed by Munuera Giner et al. (1999) who concluded that, due to the high summer temperatures, plants may allocate their resources into vegetative organs rather than into generative ones. In addition, increasing temperatures stimulate evaporation and so limits the amount of water available for plants (Zhao and Running 2010). A reduction in reproductive organs and the subsequent decrease of pollen production is one of the ways for limiting water losses (Tardieu 2013). Lowmagnitude Artemisia pollen seasons have already been linked with high temperatures and scarce rainfall in previous weeks (Munuera Giner et al. 1999; Stach et al. 2007).

In contrast, the seasonal sum of pollen of other taxa did not change significantly in Poznań. The intensity of Poaceae and Rumex pollen seasons slightly decreased, whereas Urticaceae showed a tendency towards more intense seasons, but the trend was not significant. Interestingly, during the previous study conducted in Poznań (Alcázar et al. 2009), a clear trend towards declining annual pollen counts of Rumex and Urticaceae was recorded over 1995-2005 study period. This contradiction is understandable by examining the SPI during the period 2007-2011. This is because four of the last five pollen seasons, with a SPI $>14,000$ pollen, rank among the most intense Urticaceae pollen seasons in the aerobiological record in Poznań (data not shown). It is unlikely that such strong increases in SPI are linked to favorable weather conditions, as only weak and not significant relationships were found between SPI of Urticaceae and temperature. It is therefore suggested that these variations in pollen season intensity could be modified by factors other than climate, e.g. by landuse practices.

For instance, Spieksma et al. (2000) proved that cutting Artemisia nearby the pollen trap can markedly reduce the pollen concentration on the street level. The importance of land use changes and changes in management practices has also been linked to decreasing Poaceae pollen counts, such as urbanisation reducing the amount of meadows and green areas and more frequent mowing (Stach et al. 2008; Alcázar et al. 2009; Puc and Wolski 2013). In addition, Ziello et al. (2012b) reported that the significant decreases for Amaranthaceae and Artemisia pollen season intensity could be possibly explained by intensification of weed control and less agricultural land set aside in the context of increasing bioenergy demand. Unfortunately, it is difficult to evaluate the influence of landuse practices in modifying the long-term changes in the intensity of pollen seasons without detailed analysis of land cover data as in the study of grass pollen counts in North London conducted by Emberlin et al. (1993). This, as well as the effect of other factors potentially responsible for the fluctuation in annual pollen sums, such as temporal variation in the North Atlantic Oscillation (Smith et al. 2009) and increasing level of $\mathrm{CO}_{2}$ (Ziska and Caulfield 2000; Ziska and Beggs 2012), was beyond the scope of this study.

\section{Duration on pollen seasons}

According to the Report of World Health Organization (Huynen et al. 2003), climate warming is likely to extend the duration of pollination periods of grasses and weeds. Our study concurs with this projection as significantly longer pollen seasons were seen for all examined taxa that positively correlated with increasing summer temperatures (significant for Artemisia and Poaceae). The observed lengthening of pollen seasons varied from +2.0 days/year for Urticaceae to +3.8 days/year for Rumex. Longer pollination periods of weed plants in Poznan can be attributed to the delayed pollen season end dates rather than advanced start dates. Ziska et al. (2011) showed that the increase of ragweed (Ambrosia spp.) pollen seasons in North America was primarily associated with a delay in first frost of the autumn season and lengthening of the frost free period. Similarly, rising temperatures observed in Poznań during late summer (August-September) may increase the period for plant development and pollen release. Pollen seasons of weed plants generally last longer and end later in Southern Europe compared to Central Europe, which can be attributed to more favourable weather conditions and the presence of a larger number of species (Spieksma et al. 1993; Alcázar et al. 2009). For instance, in the countries south 
of the Carpathian Mountains, i.e. in Hungary, Serbia and Bulgaria, late-flowering Artemisia species are responsible for the second peak of pollen concentrations that usually lasts till the end of September (Grewling et al. 2012b). Currently, the "autumn" peak of Artemisia pollen is rarely recorded in Poland. However, climate warming may affect migration and distribution of species (Hyvönen et al. 2011; Chuine et al. 2012) and, as a result, the composition of plant communities (Walther et al. 2002; Munson et al. 2012). These spatial changes in the long term may influence temporal variations of pollen seasons and therefore should be considered in future studies.

\section{Conclusions}

Pollen seasons of anemophilous weed taxa in Poznan changed over the 1996-2011 period. Pollination periods now start earlier for Artemisia and Poaceae, end later for Artemisia, Poaceae, Rumex and Urticaceae as well as last longer for the four taxa studied. The intensity of Artemisia pollen seasons were also found to be significantly decreasing. Of all these changes, only those of Poaceae and Artemisia were significantly correlated with recorded increases in summer temperatures, suggesting that climate warming is the main factor responsible for the observed shifts. The general lack of significant correlations between Rumex and Urticaceae pollen seasons and spring or summer temperature suggests that other factors, e.g. land use practices, could be also partially responsible for observed shifts in pollen seasons.

Acknowledgments This work was partly supported by Polish National Science Centre in frame of two projects: no. 2011/03/D/NZ7/06224 and no. 2011/01/N/ST10/05954. We would like to thank the Institute of Meteorology and Water Management for providing meteorological data.

Open Access This article is distributed under the terms of the Creative Commons Attribution License which permits any use, distribution, and reproduction in any medium, provided the original author(s) and the source are credited.

\section{References}

Adamczak A (2008) Miasto jako przestrzeń rozwoju spontanicznej roślinności drzewiastej (City as a space for the development of spontaneous woody vegetation). In: Bródka S (ed) Problemy Ekologii Krajobrazu, vol 22. Zakład Studiów Krajobrazowych, Katedra Architektury Krajobrazu SGGW, Warszawa

Alcázar P, Stach A, Nowak M, Galán C (2009) Comparison of airborne herb pollen types in Cordoba (Southwestern Spain) and Poznan (Western Poland). Aerobiologia 25:55-63

Alexandersson H (1986) A homogeneity test applied to precipitation data. Int J Climatol 6:661-675

Alexandersson H, Moberg A (1997) Homogenization of Swedish temperature data. Part I: homogeneity test for linear trends. Int J Climatol 17:25-34
Barney JN, DiTommaso A (2003) The biology of Canadian weeds. 118. Artemisia vulgaris L. Can J Plant Sci 83:205-215

Cariñanos P, Emberlin E, Galán C, Dominguez-Vilches E (2000) Comparison of two counting methods of slides from a hirst type volumetric trap. Aerobiologia 16:339-346

Chuine I, Morin X, Sonié L, Collin C, Fabreguettes J, Degueldre D, Salager J-L, Roy J (2012) Climate change might increase the invasion potential of the alien C4 grass Setaria parviflora (Poaceae) in the Mediterranean Basin. Divers Distrib 18(7):661-672

Clot B (2003) Trends in airborne pollen: an overview of 21 years of data in Neuchatel (Switzerland). Aerobiologia 19:227-234

Comtois P, Alcázar P, Néron D (1999) Pollen counts statistics and its relevance to precision. Aerobiologia 15:19-28

Cotos-Yáñez TR, Rodríguez-Rajo F, Pérez-González A, Aira MJ, Jato V (2013) Quality control in aerobiology: comparison different slide reading methods. Aerobiologia 29(1):1-11

CSO (2011) Area and population in the territorial profile in 2011. Statistical information and elaborations. Methodology, Standards and Registers Department, Central Statistical Office 2011, Warsaw

Damialis A, Halley JM, Gioulekas D, Vokou D (2007) Long-term trends in atmospheric pollen levels in the city of Thessaloniki, Greece. Atmos Environ 41:7011-7021

EEA (2012) Climate change, impacts and vulnerability in Europe 2012. An indicator-based report. European Environment Agency, Copenhagen

Emberlin J, Savage M, Jones S (1993) Annual variations in grass pollen seasons in London 1961-1990: trends and forecast models. Clin Exp Allergy 23:911-918

Emberlin J, Detandt M, Gehrig R, Jaeger S, Nolard N, Rantio-Lehtimäki A (2002) Responses in the start of Betula (birch) pollen seasons to recent changes in spring temperatures across Europe. Int $\mathrm{J}$ Biometeorol 46:159-170

Frenguelli G (2002) Interactions between climatic changes and allergenic plants. Monaldi Archives of Chest Disease 57(2):141-143

Galán C, Cariñanos P, Alcázar P, Domínguez-Vilches E (2007) Spanish Aerobiology Network (REA) Management and quality manual. Servicio de Publicaciones Universidad de Córdoba. ISBN 978-84690-6353-8

García-Mozo H, Galán C, Jato V, Belmonte J, Diaz de la Guardia C, Fernández González D, Gutierrez AM, Aira MJ, Roure JM, Mar Trigo M, Domínguez Vilches E (2006) Quercus pollen season dynamics in the Ibernian Peninsula: reponse to meteorological parameters and possible consequences of climate change. Ann Agric Environ Med 13:209-224

García-Mozo H, Galán C, Belmonte J, Bermejo D, Candau P, Díaz de la Guardia C, Elvira B, Gutiérrez M, Jato V, Silva I, Trigo MM, Valencia R, Chuine I (2009) Predicting the start and peak dates of the Poaceae pollen season in Spain using process-based models. Agric For Meteorol 149(2):256-262

García-Mozo H, Galán C, Alcázar P, Diaz de la Guardia C, Nieto-Lugilde D, Recio M, Hidalgo PJ, Gonzalez-Mineiro F, Ruiz L, Domínguez Vilches E (2010a) Trends in grass pollen season in southern Spain. Aerobiologia 26:157-169

García-Mozo H, Mestre A, Galán C (2010b) Phenological trends in southern Spain: a response to climate change. Agric For Meteorol 150:575-580

Gordo O, Sanz JJ (2009) Long-term temporal changes of plant phenology in the Western Mediterranean. Global Change Biol 15:1930-1948

Grewling Ł, Jackowiak B, Nowak M, Uruska A, Smith M (2012a) Variations and trends of birch pollen seasons during 15 years (1996-2010) in relation to weather conditions in Poznań (western Poland). Grana 51(4):280-292

Grewling Ł, Šikoparija B, Skjøth CA, Radisic P, Apatini D, Magyar D, Páldy A, Yankova R, Sommer J, Kasprzyk I, Myszkowska D, Uruska A, Zimny M, Puc M, Jäger S, Smith M (2012b) Variation in Artemisia pollen seasons in Central and Eastern Europe. Agric For Meteorol 160:48-59 
Hirst JM (1952) An automatic volumetric spore trap. Ann Appl Biol 39: 257-265

Huynen M, Menne B, Behrendt H, Bertollini R, Bonini S, Brandao R, Brown-Fährlander C, Clot B, D’Ambrosio C, De Nuntiis P, Ebi KL, Emberlin J, Orbanne EE, Galán C, Jäger S, Kovats S, Mandrioli P, Martens P, Menzel A, Nyenzi B, Rantio Lehtimäki A, Ring J, Rybnicek O, Traidl-Hoffmann, Van Vliet A, Voigt T, Weiland S, Wickman M (2003) Phenology and human health: allergic disorders. Report of a WHO meeting, Rome, Italy

Hyvönen T, Glemnitz M, Radics L, Hoffmann J (2011) Impact of climate and land use type on the distribution of Finnish casual arable weeds in Europe. Weed Res 51:201-208

Jackowiak B (1993) Atlas rozmieszczenia roślin naczyniowych w Poznaniu. Prace Zakładu Taksonomii Roślin Uniwersytetu im. Adama Mickiewicza w Poznaniu, nr 2, Poznań

Jochner S, Ziello C, Böck A, Estrella N, Buters J, Weichenmeier I, Behrendt $\mathrm{H}$, Menzel A (2012) Spatio-temporal investigation of flowering dates and pollen counts in the topographically complex Zugspitze area on the German-Austrian border. Aerobiologia 28(4):541-556

Kapyla M, Penttinen A (1981) An evaluation of the microscopical counting methods of the tape in Hirst-Burkard pollen and spore trap. Grana 20:131-141

Karl TR, Williams CNJ (1987) An approach to adjusting climatological time series for discontinuous inhomogeneities. J Appl Meteorol Climatol 26:1744-1763

Kendall MG (1975) Rank correlation methods. Charles Griffin, London

León-Ruiz E, Alcázar P, Domínguez Vilches E, Galán C (2011) Study of Poaceae phenology in a Mediterranean climate. Which species contribute most to airborne pollen counts? Aerobiologia 27:37-50

Lessard-Therrien M, Davies TJ, Bolmgren K (2013) A phylogenetic comparative study of flowering phenology along an elevational gradient in the Canadian subarctic. Int J Biometeorol. doi:10.1007/ s00484-013-0672-9

Makra L, Matyasovszky I, Deák AJ (2011) Trends in the characteristics of allergenic pollen circulation in central Europe based on the example of Szeged, Hungary. Atmos Environ 45:6010-6018

Mann HB (1945) Nonparametric tests against trend. Econometrica 13: 245-259

Matuszkiewicz W (2006) Przewodnik do oznaczania zbiorowisk roślinnych Polski. Seria Vademecum geobotanicum, PWN, Warsaw

Maw MG, Thomas AG, Stahevitch A (1985) The biology of Canadian weeds. 66. Artemisia absinthium L. Can J Plant Sci 65(2):389-400

Menzel A, Sparks TH, Estrella N, Roy D (2006) Altered geographic and temporal variability in phenology in response to climate change. Global Ecol Biogeogr 15:498-504

MPU (2008) Studium uwarunkowań i kierunków zagospodarowania przestrzennego miasta Poznania-18.01.2008. City Urban Laboratory. http://www.mpu.pl/studium2008/index.php?studium=139.

Munson SM, Webb RH, Belnap J, Hubbard JA, Swann DE, Rutman S (2012) Forecasting climate change impacts to plant community composition in the Sonoran Desert region. Global Change Biol 18(3):1083-1095

Munuera Giner M, Carrión García JS, García Sellés J (1999) Aerobiology of Artemisia airborne pollen in Murcia (SE Spain) and its relationship with weather variables: annual and intradiurnal variations for three different species. Wind vectors as a tool in determining pollen origin. Int J Biometeorol 43:51-63

Peñuelas J, Filella I (2001) Responses to a Warming World. Science 294: 793-794

Peterson TC, Easterling DR, Karl TR, Groisman P, Nicholls N, Plummer N, Torok S, Auer I, Boehm R, Gullett D, Vincent L, Heino R, Tuomenvirta H, Mestre O, Szentimrey T, Salinger J, Forland EJ, Hanssen-Bauer I, Alexandersson H, Jones P, Parker D (1998) Homogeneity adjustments of in situ atmospheric climate data: a review. Int J Climatol 18:1493-1517

Potter KW (1981) Illustration of a new test for detecting a shift in mean in precipitation series. Mon Weather Rev 109(9):2040-2045
Puc M, Wolski T (2013) Forecasting of the selected features of Poaceae (R. Br.) Barnh., Artemisia L. and Ambrosia L. pollen season in Szczecin, north-western Poland, using Gumbel's distribution. Ann Agric Environ Med 20(1):36-47

Recio M, Rodríguez-Rajo FJ, Jato V, Mar Trigo M, Cabezudo B (2009) The effect of recent climatic trends on Urticaceae pollination in two bioclimatically different areas in the Iberian Peninsula: Malaga and Vigo. Clim Change 97:215-228

Recio M, Docampo S, García-Sanchez J, Trigo MM, Cabezudo B (2010) Influence of temperature, rainfall and wind trends on grass pollination in Malaga (western Mediterranean coast). Agric For Meteorol 150:931-940

Salmi T, Maatta A, Anttila P, Ruoho-Airola T, Amnell T (2002) Detecting trends of annual values of atmospheric pollutants by the MannKendall test and Sen's slope estimates - the Excel template application MAKESENS. Finnish Meteorological Institute, Helsinki

Skjøth CA, Sommer J, Stach A, Smith M, Brandt J (2007) The long range transport of birch (Betula) pollen from Poland and Germany causes significant pre-season concentrations in Denmark. Clin Exp Allergy 37:1204-1212. doi:10.1111/j.1365-2222.2007.02771.x

Skjøth CA, Smith M, Sikoparija B, Stach A, Myszkowska D, Kasprzyk I, Radisic P, Stjepanovic B, Hrga I, Apatini D, Magyar D, Páldy A, Ianovici N (2010) A method for producing airborne pollen source inventories: an example of Ambrosia (ragweed) on the Pannonian Plain. Agric For Meteorol 150:1203-1210

Smith M, Emberlin J, Stach A, Rantio-Lehtimäki A, Caulton E, Thibaudon M, Sindt C, Jäger S, Gehrig R, Frenguelli G, Rodríguez-Rajo FJ, Alcázar P, Galán C (2009) Influence of the North Atlantic Oscillation on grass pollen counts in Europe. Aerobiologia 25(4):321-332

Solomon S, Qin D, Manning M, Chen Z, Marquis M, Averyt KB, Tignor M, Miller HL (eds) (2007) Contribution of Working Group I to the Fourth Assessment Report of the Intergovernmental Panel on Climate Change. Cambridge University Press, Cambridge

Soudani K, Hmimina G, Delpierre N, Pontailler JY, Aubinet M, Bonal D, Caquet B, de Grandcourt A, Burban B, Flechard C, Guyon D, Granier A, Gross P, Heinesh B, Longdoz B, Loustau D, Moureaux C, Ourcival JM, Rambal S, Saint Andre L, Dufrene E (2012) Ground-based Network of NDVI measurements for tracking temporal dynamics of canopy structure and vegetation phenology in different biomes. Remote Sens Environ 123:234-245

Sparks TH, Górska-Zajączkowska M, Wójtowicz W, Tryjanowski P (2011) Phenological changes and reduced seasonal synchrony in western Poland. Int J Biometeorol 55:447-453

Spieksma FTM, Nolard N, Frenguelli G, Van Moerbeke D (1993) Pollens de l'air en Europe. Braine-l'Alleud, Belgique

Spieksma FT, van Noort P, Nikkels AH (2000) Influence of nearby stands of Artemisia on street-level versus roof-top-level ratio's of airborne pollen quantities. Aerobiologia 16:21-24

Stach A (2000) Variation in pollen concentration of the most allergenic taxa in Poznan (Poland), 1995-1996. Aerobiologia 16:63-68

Stach A, García-Mozo H, Prieto-Baena JC, Czarnecka-Operacz M, Jenerowicz D, Silny W, Galán C (2007) Prevalence of Artemisia species pollinosis in Western Poland: impact of climate change on aerobiological trends, 1995-2004. J Investig Allergol Clin Immunol 17(1):39-47

Stach A, Smith M, Prieto Baena JC, Emberlin J (2008) Long-term and shortterm forecast models for Poaceae (grass) pollen in Poznań, Poland, constructed using regression analysis. Environ Exp Bot 62:323-332

Stepanek P (2008a) AnClim - software for time series analysis. Dept. of Geography, Fac. of Sciences, Masaryk University, Brno. http:// www.climahom.eu.

Stepanek P (2008b) ProClimDB - software for processing climatological datasets. CHMI, regional office Brno. http://www.climahom.eu/ ProcData.html 
Tardieu F (2013) Plant response to environmental conditions: assessing potential production, water demand, and negative effects of water deficit. Front Physiol 4(17):1-11

Tormo R, Silva I, Gonzalo A, Moreno A, Perez R, Fernandez S (2011) Phenological records as a complement to aerobiological data. Int $\mathrm{J}$ Biometeorol 55:51-65

Tormo-Molina R, Munoz-Rodriguez A, Silva-Palacios I (1996) Sampling in aerobiology. Differences between traverses along the length of the slide in Hirst spore traps. Aerobiologia 12:161-166

Tormo-Molina R, Gonzalo-Garijo A, Silva-Palacios I, MuñozRodríguez A (2010) General Trends In Airborne Pollen Production And Pollination Periods At a Mediterranean Site (Badajoz, Soutwest, Spain). J Investig Allergol Clin Immunol 20(7):567-574

Van Vliet A, Overeem A, De Groot R, Jacobs A, Spieksma FT (2002) The influence of temperature and climate change on the timing of pollen release in the Netherlands. Int J Climatol 22: $1757-1767$

Venema VKC, Mestre O, Aguilar E, Auer I, Guijarro JA, Domonkos P, Vertacnik G, Szentimrey T, Stepanek P, Zahradnicek P, Viarre J, Muller-Westermeier G, Lakatos M, Williams CN, Menne MJ, Lindau R, Rasol D, Rustemeier E, Kolokhytas K, Marinova T, Andersen L, Acquaotta F, Fratianni S, Cheval S, Klancar M, Brunetti M, Gruber C, Prohom Duran M, Likso T, Esteban P, Brandsma $\mathrm{T}$ (2012) Benchmarking homogenization algorithms for monthly data. Clim Past 8:89-115

Vincent LA, Zhang X, Bonsal BR, Hogg WD (2002) Homogenization of daily temperatures over Canada. J Clim 15:1322-1334

von Wahl PG, Puls KE (1989) The emission of mugwort pollen (Artemisia vulgaris L.) and its flight in the air. Aerobiologia 5:55-63

Walther G-R, Post E, Convey P, Menzel A, Parmesan C, Beebee TJC, Fromentin J-M, Hoegh-Guldberg O, Bairlein F (2002)
Ecological responses to recent climate change. Nature 416: 389-395

Wolf F, Puls KE, Bergmann KC (1998) A mathematical model for mugwort (Artemisia vulgaris L.) pollen forecasts. Aerobiologia 14: 359-373

Woś A (2010) Klimat Polski w drugiej połowie XX wieku. Wydawnictwo Naukowe UAM, Poznań

Zhao M, Running SW (2010) Drought-induced reduction in global terrestrial net primary production from 2000 through 2009. Science 329(5994):940-943

Ziello C, Böck A, Estrella N, Ankerst D, Menzel A (2012a) First flowering of wind-pollinated species with the greatest phenological advances in Europe. Ecography 35:1017-1023

Ziello C, Sparks TH, Estrella N, Belmonte J, Bergmann KC, Bucher E, Brighetti MA, Damialis A, Detandt M, Galan C, Gehrig R, Grewling Ł, Gutierrez AM, Hallsdottir M, Kockhans-Bieda M-C, De Linares C, Myszkowska D, Paldy A, Sanchez A, Smith M, Thibaudon M, Travaglini A, Uruska A, Valencia Barrera RM, Vokou D, Wachter R, De Weger LA, Menzel A (2012b) Changes to airborne pollen counts across Europe. PLoS ONE 7(4):e34076

Ziska LH, Beggs PJ (2012) Anthropogenic climate change and allergen exposure: The role of plant biology. J Allergy Clin Immunol 129(1): $27-32$

Ziska LH, Caulfield FA (2000) Rising $\mathrm{CO}_{2}$ and pollen production of common ragweed (Ambrosia artemisiifolia), a known allergyinducing species: implications for public health. Aust J Plant Physiol 27(10):893-898

Ziska LH, Knowlton K, Rogers C, Dalan D, Tierney N, Elder MA, Filley W, Shropshire J, Ford LB, Hedberg C, Fleetwood P, Hovanky KT, Kavanaugh T, Fulford G, Vrtis RF, Patz JA, Portnoy J, Coates F, Bielory L, Frenz D (2011) Recent warming by latitude associated with increased length of ragweed pollen season in central North America. Proc Natl Acad Sci U S A 108(10):4248-4251 